\title{
Modeling HTLV-lymphomagenesis: immune activation induces immortalization and leukemogenicity of HTLV-I LTR-Tax transgenic CD4+T-cells
}

\author{
Alison Y Swaims ${ }^{1,2,3}$, Celine Granier ${ }^{1,2}$, Francesca Khani ${ }^{3}$, Yingyu Zhang2, \\ Arthur I Roberts ${ }^{2}$, Satish Devadas ${ }^{2}$, Yufang Shi ${ }^{2,3}$ and Arnold B Rabson*1,2,3
}

\begin{abstract}
Address: ${ }^{1}$ Child Health Institute of New Jersey, University of Medicine and Dentistry of New Jersey (UMDNJ), Robert Wood Johnson Medical, School (RWJMS), 89 French Street, New Brunswick, New Jersey 08901, USA, ${ }^{2}$ Department of Molecular Genetics, Microbiology, and Immunology UMDNJ-RWJMS, 661 Hoes Lane, Piscataway, New Jersey 08854, USA and ${ }^{3}$ Cancer Institute of New Jersey UMDNJ-RWJMS, 179 Little Albany Street, New Brunswick, NJ 08903, USA

* Corresponding author
\end{abstract}

from Frontiers of Retrovirology: Complex retroviruses, retroelements and their hosts

Montpellier, France. 21-23 September 2009

Published: 24 September 2009

Retrovirology 2009, 6(Suppl 2):P73 doi:10.1 I86/I742-4690-6-S2-P73

This abstract is available from: http://www.retrovirology.com/content/6/S2/P73

(c) 2009 Swaims et al; licensee BioMed Central Ltd.

\section{Background}

Infection with the human T-cell leukemia virus-1 (HTLV1) results in a variety of diseases including adult T-cell leukemia/lymphoma (ATL). The pathogenesis of these disorders is poorly understood, however involves complex interactions with the host immune system. Previous studies from our laboratory and others have suggested that immune activation of infected T-cells increases the expression of the oncogenic HTLV-1 Tax transactivator protein from integrated HTLV-1 proviruses [1]. Thus, we have hypothesized that immune activation of infected Tcells may play an important role in disease pathogenesis through Tax induction, leading to increased proliferation of infected cells. To study this hypothesis, we employed transgenic mice in which Tax is regulated by the HTLV-1 LTR. These mice were previously shown to develop neurofibromas, but do not express Tax in T cells and do not develop lymphomas [2].

\section{Results}

A single round of T-cell receptor-stimulation of transgenic mouse LTR-Tax CD4+T-cells induced Tax expression, hyperproliferation, and immortalization in culture. The transition to cellular immortalization was accompanied by markedly increased expression of the anti-apoptotic gene, $m c l-1$, previously implicated as important in T-cell survival. Immortalized cells exhibited a CD4 ${ }^{+} \mathrm{CD} 25^{+} \mathrm{CD} 3^{-}$ phenotype commonly observed in ATL. Engraftment of immune-activated LTR-Tax CD4+T-cells into NOD/Shiscid/IL-2R $\gamma$ null mice resulted in a leukemia-like phenotype with expansion and tissue infiltration of Tax+, CD4+lymphocytes. Furthermore, immune activated Tax CD4+ T-cells express CD4+ cell subset characteristics of several different CD4+ T-cell subtypes, including Th1, Th2, and Th17 cells, suggesting that HTLV-1 Tax induces changes in the normal pattern of CD4+ subtype specification. On-going studies are also employing retroviralmediated, insertional mutagenesis to identify cellular genes that may collaborate with Tax in the induction of Tcell lymphomas in the HTLV-1 LTR-Tax transgenic mice.

\section{Conclusion}

Immune activation of infected CD4+T-cells results in the induction of Tax expression in CD4+cells from LTR-Tax transgenic mice as well as in infected human CD4+T-cells. This may lead to T-cell proliferation, additional genetic alterations, cellular immortalization and pathogenesis of HTLV-1-asssociated diseases including ATL in infected individuals. 


\section{References}

I. Lin HC, Dezzutti CS, Lal RB, Rabson AB: Activation of human Tcell leukemia virus type I tax gene expression in chronically infected T cells. J Virol 1998, 72:6264-6270.

2. Nerenberg M, Hinrichs SH, Reynolds RK, Khoury G, Jay G: The tat gene of human T-lymphotropic virus type I induces mesenchymal tumors in transgenic mice. Science 1987, 237:1324-1329.

Publish with Bio Med Central and every scientist can read your work free of charge

"BioMed Central will be the most significant development for disseminating the results of biomedical research in our lifetime. " Sir Paul Nurse, Cancer Research UK

Your research papers will be:

- available free of charge to the entire biomedical community

- peer reviewed and published immediately upon acceptance

- cited in PubMed and archived on PubMed Central

- yours - you keep the copyright

Submit your manuscript here:

http://www.biomedcentral.com/info/publishing_adv.asp 